\title{
POSITION DETERMINATION STRATEGIES OF STAR HOTELS IN BANDUNG
}

\author{
Ananta Budhi Danurdara ${ }^{1}$ \\ Bandung Tourism Institute \\ ananta.budhi.d@gmail.com
}

\author{
Wishnu Wardhana ${ }^{2}$ \\ Bandung Tourism Institute \\ wiw@stp-bandung.ac.id
}

\author{
Rachmat Muljawan ${ }^{3}$ \\ Bandung Tourism Institute
}

\begin{abstract}
In marketing, differentiation strategy has basic functions to achieve the company's objectives, both at the level of strategic marketing and tactical marketing level. Through differentiation, the company can determine the desired position among competing companies. Effective differentiation is a complex process and in its design involves many parties within the company, so it requires a high synergy between these parties. The implementation of service product differentiation strategy is an act that should be done by a hotel to increase the occupancy rate. The conceptual model of differentiation strategy includes service product offering differentiation (content), service product delivery differentiation (contect) and service product image differentiation (image). Position determination and service product differentiation strategy implementation performed by the management of star hotels in Bandung needs to be improved optimally, so that the level of competition (competitive advantage) will be high. That is the reasons that the hotel management needs to determine the position of his hotel service products to be competitive with the other hotels. The research objects are star hotels in Bandung, while respondents are hospitality experts. The data collection is nonsampling. The analysis is done through a multidimensional scalling. The results of analsisis showed that positioning determination done by the hotel management has been implemented properly.
\end{abstract}

Keyword: differentiation, positioning, content, contect, image, hotel

\section{BACK GROUND}

One important means to support tourism activities is a hotel. Hotel Proprietors Act define, "Hotel is a company managed by its owner to provide services of food, beverage, and rooms for sleeping to people who are traveling and able to pay the amount that is reasonable in accordance with the services received without their special agreement". So the hotel is part of the tourism business and can be regarded as a commercialized business of accommodation with facilities such as guest rooms, meals and drinking as well as other services. The marketing approach of 4P (product, place, price and promotion) [11] which is traditional approach has often successful for selling goods, but various additional elements require more attention in the service business. [15] suggests extra $3 \mathrm{P}$ that is involved in the service process i.e. people, process, and physical evidence.

Bandung nowadays is one of the leading tourist destinations, the tourism development in Bandung is supported by the availability and variety of products of urban tourism, and culture that supported by adequate tourism infrastructure and facilities. The vision of Bandung, namely: "Enhancing the role of Bandung as city of services business, towards the realization of the Bandung city as neat-organizedcomfortable (genah merenah tumaninah)." Bandung City Government has set the tourism sector as mainstay in order to generate income for the region, opening the job opportunities, and service to the community. Until 2007 the number of tourists visiting Bandung was $1,837,500$ for domestic tourists and 91,350 for international tourists. While the percentage of growth in the 2003-2005 period was $9.5 \%$ (domestic tourists) and 6\% (international tourists). 
One strategy to improve the business of hospitality services in Bandung is through the "positioning strategy", which is a way of strategic positioning of service products owned by the hotel compared with services products of its competitor. Services are oriented as far as possible to the effort of creating guest satisfaction. The orientation is the result of the intense competition in the hospitality business and the shift of guests' motivation that tend to be more flexible. Also due to the development of guests knowledge about hotel service offers and hotel delivery of products, so that the guests will tend to be more critical to the high quality of hospitality services.

Based on the above discussion, researchers then produce a problem statement that lots of guests staying in hotels in Bandung are still not feel satisfied. This is caused by, among others, positioning through service product differentiation strategy and service product marketing strategy performed by hotel management has not been implemented optimally, so this will affect the satisfaction level of guests staying. This finding is quite interesting and worth researching based on the study of strategic management, namely in terms of marketing. This research will be focused on identifying to what extent the similarity and dissimilarity (similarity) started from the supply and delivery of product of star hotels in Bandung.

\section{Formulation of the problem}

This study limits the issue only of position determination of the offer and delivery of products performed by star hotels in Bandung. Based on the description of the background and problem limitation above, the researchers can formulate the problem as follows:

1. How does the similarity and difference of the product offering of star hotels in Bandung?

2. How does the similarity and difference of product delivery of star hotels in Bandung?

\section{Research Objectives and Purpose}

The purpose of this study was to determine how the similarity and difference (Similarity) of service products offering and delivery of star hotels in Bandung. By knowing the similarity and difference (Similarity) of offering and delivery of service products of star hotels in Bandung will ease the management in realizing its vision and mission. This will have an impact on the improvement of number of guests staying at star hotels in Bandung.

\section{Framework}

In defending the survival of business, every company whether a company engaged in the field on manufacture as well as companies engaged in service products, such as the hospitality, always have to strive for excellence in a particular field to win the competition (competitive advantage) in this case is the excellence of service product provision to customers, therefore a good strategic marketing planning is needed.

\section{Strategic Marketing Planning (Positioning)}

Based on Figure I.1, the Conceptual framework for marketing planning, [9] says there are some components that must be considered in determining strategic marketing planning by a company, especially in terms of determining the "positioning strategy" or position determination strategy, i.e. :

1. Companies need to do a "Competitive Analysis" to the service products offered by a competitor. This is done to determine what services products are offered by a competing company of its kind. Companies can find out the strengths and weaknesses of the product and services offered by a competitor. Then "product differentiation" is needed to be offered to consumers. The essence of "product differentiation" is the answer of what to do toward the service products? While differentiation according to [9] is the act of designing a set of meaningful differences to distinguish the company's offerings from competitors' offerings. Differentiation of the offer, delivery and imagery can be classified into five dimensions: product differentiation, service differentiation, differentiation of personnel, channel differentiation and differentiation image.

2. Once the strengths and weaknesses of competitors' service products, the company will need to do "Corporate Self-Analysis", an analysis of the strengths and weaknesses of service products owned by the company itself compared with competitors' products. The company carries out internal analysis of these through structure, culture and resources dimensions. 
3. The Company also need to conduct "Customer Analysis" is to determine the characteristic shape of the consumer needs, desires and demands. Companies also need to do "market differentiation" that divide the market company carries out market segmentation to divide the heterogeneous market into homogeneous groups, namely those who have the similar needs and desires of the same products as well. and determine the target market. The

Figure 1 : Conceptual framework for marketing planning

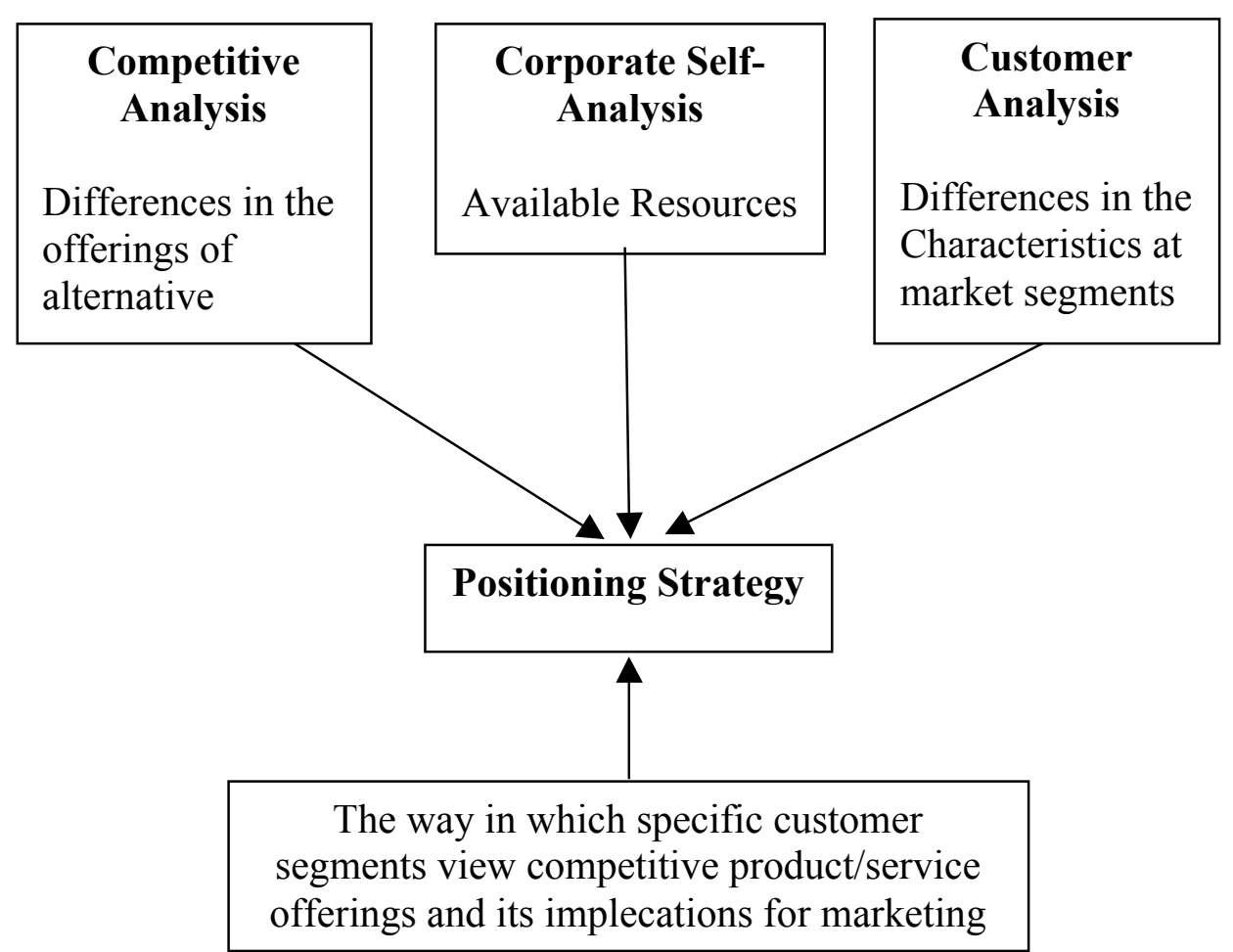

Source : Erdener Kaynak, 1994

So in determining the "Positioning Strategy" of a company, it takes some analysis to be done by the management i.e. the competitive analysis, corporate selfanalysis, and customer analysis. It is very necessary, especially in the determination of marketing planning strategy which is to determine the position of service products offer to consumers.

\section{Hypothesis}

1. There is a similarity and dissimilarity (Similarity) of the product offering of star hotels in Bandung.
2. There is a similarity and dissimilarity (Similarity) of product delivery of star hotels in Bandung.

\section{Literature Review}

\section{Position Determination Strategy}

Every company should position the products or services offered to customers. These activities require analysis and research. [9] defines positioning as: "The act of designing the company's offering and image so that they occupy a meaningful and distinct competitive position of the targeted customers mind." Which means "Positioning is an action of marketers to create image 
products and things to offer to market successfully acquired a clear position and means in the minds of target consumers ".

This was confirmed by Heibing and [2] saying: "Positioning establishes the desired perception of your product within the target market relative to the competition". (Positioning builds the perception of your product in the target market relative to competition). Position determination is to create an image that reflects how a product or service that is owned by the company compared with competitors in the most important dimensions for success in the industry.

\section{Steps positioning:}

1. Choose the key criteria that effectively differentiate products in the industry.

2. Make a diagram of a twodimensional map of positioning the product or service to the criteria set for each axis.

3. Placing the products or services of a competitor in the resultant matrix of four quadrants.

4. Identify the field in a position where the product or service can compete in a specific target market. Looking for a vacant field (niche).

5. Develop a marketing plan to position the company's products or services appropriately.

Some basic guidelines for using the product positioning as a tool to implement the strategy are as follows:

1. Look for an empty niche. The best opportunity strategy may be the segment that no one serving.

2. Do not put yourself in between segments. All the advantages of being in between the segments eliminated by the failure to satisfy one segment.

3. Do not serve two segments with the same strategy.

4. Do not position the product or service in the midst of the map.
The pricing strategy for effective product positioning services must meet two criteria:

1) It uniquely distinguishes a company from its competitors.

2) Make customers expect service slightly below that can be given by the company. Companies should not create expectations that exceed the company's services can be provided.

\section{Developing Strategy of Positioning}

A distinction can be made if it meets the following criteria:

a. Important

Differences that provide high value for the benefit of adequate lots of buyers.

b. Unique

The difference was not offered by anyone or by more companies.

c. Superior

Differences are superior compared to other ways to get the same benefits.

d. Communicatable

That difference can be communicated and clearly visible to purchasers.

e. Precede

The difference is not easily imitated by competitors

f. Affordable

Buyers can afford to pay the difference.

g. Pprofitable

The company will make a profit by introducing a distinction.

\section{Some positioning strategy:}

a. Positioning by attributes. A company is positioning itself by attributes.

b. Positioning by benefits. The product is positioned as a leader in a particular benefit.

c. Positioning according to usage. Is positioned as the best product for a use or application 
d. Determination of the position according to the wearer. The product is positioned as the best for a number of user groups.

e. Positioning by competitors. The products are positioned as better than the competitors mentioned by name.

f. Positioning by product category. Here the product is positioned as a leader in a product category.

g. Positioning the price. The product is positioned as offering the best price value.

\section{RESEARCH METHODS}

The method used in this research is descriptive research method, i.e. a research method that aims to describe a phenomenon or phenomena. Researchers describe how the similarity and dissimilarity (Similarity) of star hotels in Bandung.

\section{Object of Research}

As object in this study are star hotels located in Bandung. While respondents are expert groups that is public figures such as Academic figures in hospitality field, the tourism community organizations (NGOs) that have a concern in the business of accommodation services.

\section{Research Variable}

The variables of this research are the marketing mix.

Table 1 : Operationalization of Research Variables

\begin{tabular}{|c|c|c|c|}
\hline VARIABLE & $\begin{array}{l}\text { SUB- } \\
\text { VARIABLE }\end{array}$ & CONCEPT & INDICATORS \\
\hline \multirow[t]{7}{*}{$\begin{array}{l}\text { Mix } \\
\text { Marketing of } \\
\text { Service }\end{array}$} & Product & $\begin{array}{l}\text { Tangible business offers to the market that } \\
\text { includes quality, shape, brand and packaging. As } \\
\text { part of its product offerings, the company provides } \\
\text { a variety of services. }\end{array}$ & $\begin{array}{l}\text { - Product } \\
\text { Variation } \\
\text { - Fasilities } \\
\text { - Uniqueness }\end{array}$ \\
\hline & Price & $\begin{array}{l}\text { The amount of money that customers pay for } \\
\text { certain products. Companies must decide the price } \\
\text { discounts, credit terms. The price should be } \\
\text { proportional to the value offering to customers. }\end{array}$ & $\begin{array}{l}\text { - Package price } \\
\text { - Discount }\end{array}$ \\
\hline & Place & $\begin{array}{l}\text { Marketing facilities to provide products and } \\
\text { services to its target market. }\end{array}$ & - Strategic \\
\hline & Promotion & $\begin{array}{l}\text { The activities of the company to communicate and } \\
\text { promote their products to the target market. }\end{array}$ & $\begin{array}{l}\text { - Message } \\
\text { - Media }\end{array}$ \\
\hline & People & $\begin{array}{l}\text { Service company can differentiate itself by } \\
\text { recruiting and training employees who are more } \\
\text { capable and more reliable in dealing with } \\
\text { customers, employees of the competitors. }\end{array}$ & $\begin{array}{l}\text { - Speed } \\
\text { - Friendliness }\end{array}$ \\
\hline & $\begin{array}{l}\text { Physical } \\
\text { Environment }\end{array}$ & $\begin{array}{l}\text { The service company can develop a physical } \\
\text { environment that is more attractive. }\end{array}$ & $\begin{array}{l}\text { - Environment } \\
\text { - Building }\end{array}$ \\
\hline & Process & $\begin{array}{l}\text { The service company can design the process of } \\
\text { delivering superior services, eg home hotel formed } \\
\text { by the particular hotel. }\end{array}$ & $\begin{array}{l}\text { - Reservation } \\
\text { - Ci-Co }\end{array}$ \\
\hline
\end{tabular}

\section{Data Collection Procedures - Population, Sample, Sampling}

The population in this study is the total number of players in the industry of accommodation service business in Bandung, while the sample is some of those players. The sampling is purposive sampling i.e. taking the sample unit of the population under consideration and a particular purpose.

\section{Scoping:}

Researchers will expand knowledge about the hospitality in Bandung by interviewing the parties related to the hospitality industry 
such as the industry, the government and the community parties in Bandung.

\section{Questionnaires Design:}

Researchers will conduct the survey by giving questionnaires to the respondents in this case are people who are accommodation service business persons in Bandung. This questionnaire will reveal information about the similarity and dissimilarity of products of hotels in Bandung. The questionnaire was made based on the ranking scale with five alternative answers. A comment or suggestion will be included here as well.

\section{Logistics:}

The questionnaire was made with the help of the computer, and then reproduced for distribution to the respondent. Filling the questionnaire carried out with the guidance of tutors / surveyor.

\section{Trials :}

Prior to distribution, the questionnaires were tried in advance to a small number of respondents. This is done to know the level of reliability and validity of the questionnaire.

\section{DATA ANAYSIS OF MULTIDIMENSIONAL SCALLING}

Analysis Multidimensional Scaling (MDS) is used to determine the interdependent relationship or interdependence of cause variable (dependent). MDS is associated with the creation of graphs (map) that depicts the positions of the object of study compared with other objects. The analysis is presented in the form of the perception of two-dimensional map that is divided into four quadrants. Each quadrant form a array unit of objects based on similarities (similarity) or dissimilarity (dis-similarity) of each object is compared. The objects represented as points in a multidimensional attribute space, where the distance of the object with the other is a measure of the difference between those objects. The general formula of Multidimensional Scaling is:

$$
\operatorname{Dij}=\left\{\sum|X i j-X j k|\right\}^{1 / 2}
$$
with Xjk.

Where Dij : Distance between Xij

\section{Analysis and Discussion of Hotel Services Product Positioning}

The field data obtained then analysed by using analysis Multidimensional Scaling (MDS) of the five hotel in Bandung concerning services product offerings and service product delivery with the help of computer program package SPSS v.15.00. The results obtained as follows:

\section{a. Iteration history for the two dimensional solution (in squared distances).}

Iteration of Young's the S-Stress used to optimize the results obtained. With the help of a computer program SPSS, the results obtained as follows:

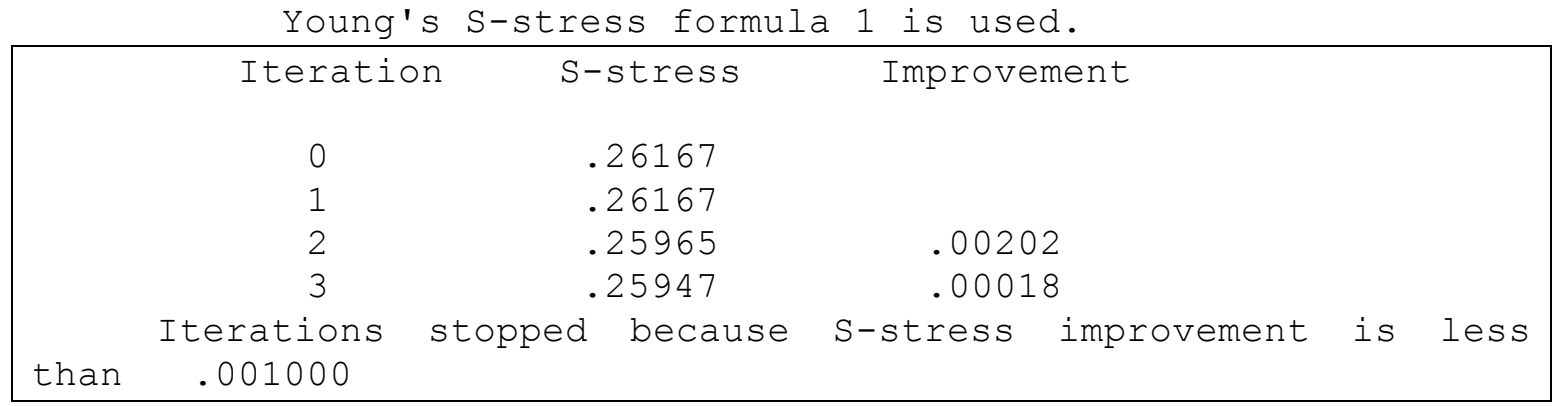

The above shows that iteration stops, because the score of S-Stress Improvement that is 0.00018 smaller than 0.001000 . 


\section{b. $\quad$ Stress and squared correlation (RSQ) in distances}

RSQ values are the proportion of variance of the scaled data (disparities) in the partition (row, matrix, or entire data) that is accounted for by their corresponding distances.

\begin{tabular}{|c|c|c|c|c|c|}
\hline St & values & are Kruskal' & 's stres & formula 1. & \\
\hline Matrix & Stress & RSQ & Matrix & Stress & $\mathrm{RSQ}$ \\
\hline 1 & .216 & .813 & 2 & .134 & .954 \\
\hline 3 & .175 & .874 & 4 & .153 & .883 \\
\hline 5 & .217 & .794 & 6 & .133 & .935 \\
\hline 7 & .220 & .748 & 8 & .136 & .951 \\
\hline 9 & .274 & .639 & 10 & .193 & .894 \\
\hline 11 & .215 & .798 & 12 & .250 & .692 \\
\hline 13 & .144 & .898 & 14 & .130 & .919 \\
\hline 15 & .095 & .955 & 16 & .223 & .775 \\
\hline 17 & .242 & .706 & 18 & .138 & .902 \\
\hline 19 & .127 & .946 & 20 & .201 & .816 \\
\hline 21 & .162 & .870 & 22 & .170 & .891 \\
\hline 23 & .243 & .697 & 24 & .239 & .706 \\
\hline 25 & .172 & .870 & 26 & .190 & .844 \\
\hline 27 & .242 & .719 & 28 & .117 & .934 \\
\hline \multirow[t]{3}{*}{29} & .248 & .689 & 30 & .164 & .878 \\
\hline & Average & d (rms) over & \multicolumn{2}{|c|}{ matrices } & \\
\hline & $\operatorname{ess}=$ & .19137 & $\mathrm{RSQ}=$ & .83297 & \\
\hline
\end{tabular}

The result of SPSS process above that the average score of Stress is 0,19137 . This value close to 0,0000 (zero) meaning that there is similarity (homogen) among respondents in answering the five object hotels in Bandung. While RSQ value obtained 0.83297 or $83.297 \%$, which shows the proportion of the variance.

\section{c. Configuration derived in $\mathbf{2}$ dimensions}

Here is the determination of the coordinates in two-dimensional map is as follows:

\begin{tabular}{|c|c|c|c|}
\hline \multicolumn{4}{|c|}{$\begin{array}{c}\text { Stimulus Coordinates } \\
\text { Dimension }\end{array}$} \\
\hline $\begin{array}{l}\text { Stimulus } \\
\text { Number }\end{array}$ & $\begin{array}{l}\text { Stimulus } \\
\text { Name }\end{array}$ & 1 & 2 \\
\hline 1 & homann & 1.0391 & .3306 \\
\hline 2 & preanger & .9181 & -.0812 \\
\hline 3 & panghega & .4401 & .3634 \\
\hline 4 & horison & -1.2702 & 1.2043 \\
\hline 5 & papanday & -1.1270 & -1.8171 \\
\hline
\end{tabular}

From the results of SPSS above can be seen that the magnitude of the coordinates of a point in two-dimensional (X, Y) of the five hotels were compared.

\section{d. Derived Stimulus Conviguration}


Here is deployment configuration of the five hotels in Bandung, which is presented in the form of a map. As shown in the following figure:

Figure 2 : Map Product Positioning of Hotel Services

Derived Stimulus Configuration

Individual differences (weighted) Euclidean distance model

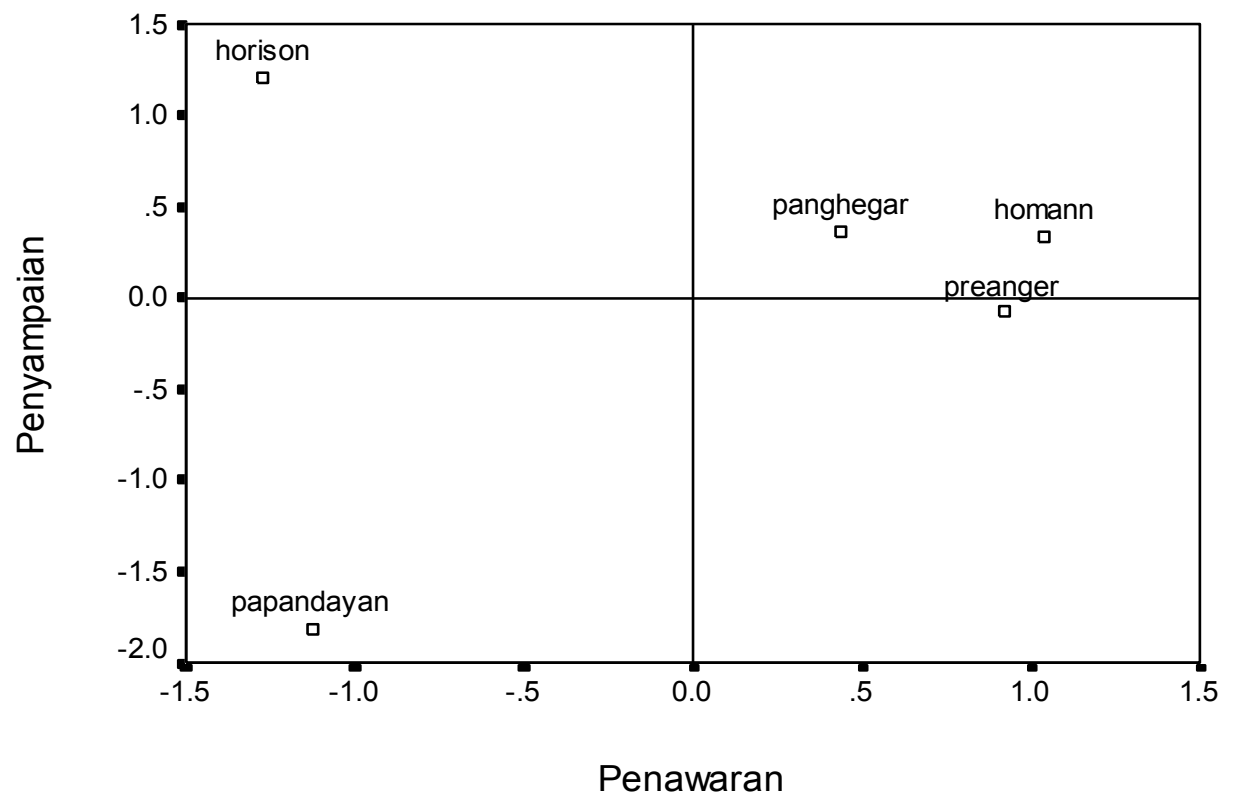

Explanation:

Dimension 1 : Offering (offering/content) : product and price.

Dimension 2 : Delivery (delivering/contect) : distribution and promotion.

\section{Analysis by Position}

From above figure shows that Homann, Preanger, and Panghegar is located adjacent to and in the same quadrant and form a separate cluster. This shows that there are similarities among the three hotels, both in terms of product offering services, both (product and price) and in terms of delivery (distribution and promotion). The three hotel form a separate cluster and the clusters differentiate from the other hotels i.e. Papandayan hotel cluster and Horison hotel cluster. As for Papandayan and Horizon hotels located far away and form a separate cluster.

The results of field data showed that the three hotels that make up the cluster of its own, namely Homann, Panghegar, and Preanger, when seen from the supply side, i.e. to the dimensions of the product (uniqueness, suitability, style and design) has a similar resemblance that differentiates it from other clusters hotel.

Similarly, for the dimensions of service (reservations, pricing, guarantees) and personnel-dimensional (speed and friendliness) also has a similar resemblance. When viewed from the sub-variable of delivery (channel) such as location, promotion, physical environment, all three hotels of Homann, Panghegar, and Preanger also have the similarities that differentiate from the other hotel cluster.

All three hotels of Homann, Preanger and the Panghegar form a separate cluster and have the same similarities as compared to other hotel 
groups i.e. Papandayan and Horizon hotels. Both Papandayan and Horizon hotel also form a separate cluster, because they are located too far at different quadrants.

So, from the above figure three groups of clusters it can be formed that show similarity/dissimilarity of supply and delivery from the point of view of respondents.

\section{Dimension Based Analyses \\ - Dimensions 1. (Differentiation of Offer).}

From Figure 4.1. above shows that to the right, dimension 1 number is greater. It also appears that Homann, Preanger and the Panghegar closest to dimension 1 figure of the largest dimension (right at the edge of the horizontal line).

This means that the three hotels has factors in dimension 1, namely the differentiation of offers (product and price) that highly distinguished compared to other hotels that is Papandayan and Horizon hotels. It can be said also that the product offering and pricing of the three hotels are the similar as compared to other factors. While Papandayan and Horizon hotel are located at leftmost horizon due to the small numbers, it is in the minds of respondents that factors of offering (product and price) is not a factor that sets it apart compared to other hotels.

Offer of service products of the three hotel is similar. Indications from the field proves that the products that is offered such as uniqueness, suitability, style and design has a similar resemblance. Similarly, for the dimensions of services such as reservations, pricing, guarranties and personnel dimensions such as speed, friendliness, communication, and the appearance is also have similar resemblance.

- Dimensions 2. (Differentiation of Delivery) The above figure shows that the higher the position, the higher the number of dimension 2 that is dimension of delivery. It also appears that the Horizon, Homann and Panghegar hotels are located closest to the greatest number of dimension 2 (at the tip top vertical line). It can be concluded that the differentiation factors, namely the delivery of distribution and promotion by the three hotels above form a separate cluster and form factor that most distinguishes compared to other hotels. Hotel Papandayan, located at the bottom with the smallest number, so factors of service product delivery differentiation is not something distinguishing from other hotels.

Indication of field indicates that the delivery is carried out by hotel horizon such as distribution, location and promotion show different characteristics compared with other hotels. Likewise, the differentiation submission made by Homann and Preanger has different characteristics, especially in terms of target market segments.

By knowing these information, management can develop several alternative strategies. Preferably for hotels that exist in each cluster:

1. Hotels do not have to compete for the same clusters, since in the eyes of respondents hotels that have many similarities, both in terms of product offering differentiated services or the delivery of product differentiation in terms of services.

2. Use a different strategy, because the hotel had the differentiation of the offer and the delivery that is similar in the minds of respondents.

3. For cluster two and cluster three because it has the most distinguishing variables in terms of differentiation of supply and delivery dimensions, so the hotel can improve the facilities like products, services, personnel, reservation and promotion.

\section{CONCLUSION}

Based on the analysis and discussion of the position, researchers can conclude some of the following:

1. Implementation of service product positioning strategy performed by the management of star hotels in Bandung is already good. This is evident from the analysis of data obtained in the field that the positioning strategy, 
especially in terms of supply differentiation, differentiation of product delivery services are already on the desired position by the hotel management. Service product positioning strategy implementation as one function of the marketing strategies that are fundamental and is one of the strategic alternatives to optimize hotel revenue results. Service product positioning strategy includes product positioning and differentiation of delivery done by the management of hotels in Bandung already good.

2. From the research results it is known that the hotel Homann, Preanger and the Panghegar form a separate cluster and have the same similarities as compared to other hotel groups. On the other hand Horison and Papandayan hotels also form a separate cluster, because they are too far apart and exist in different quadrants. So it can be formed three groups of hotel clusters that show similarities / dissimilarity of supply and delivery from the view of respondents.

\section{SUGESTION}

1. Hotel management in determining the position placement strategy must remain consistent and competitive. One of the concepts that can be applied by the industry is the pricing strategy for the following positions:

- Choose the key criteria to effectively differentiate their products / services in the industry.

- Make a diagram of a twodimensional map positioning products with criteria defined in each axis. Placing the products and services of a competitor in the resultant matrix of four quadrants. identify areas in a position where the product or service can compete in a specific target market. Looking for a vacant field (niche). Develop a marketing plan to position the company's products or services appropriately. Some basic guidelines for using the product positioning as a tool to implement the strategy are as follows:

- Look for an empty niche. Opportunities may be the best strategy is the segment that no one serving. Do not put yourself between segments. All the advantages of being in between the segments eliminated by the failure to satisfy one segment. Do not serve two segments with the same strategy. Do not position your products and services in the midst of the map.

The pricing strategy for positioning products and services that effectively meet two criteria:

- By uniquely distinguishes a company from its competitors.

- Make customers expect service slightly below that can be given by the company. Companies should not create expectations that exceed the company's services can be provided.

2. Implementation service product differentiation strategy as the basis of marketing functions, it requires a variety of accurate information in order to predict number of guests staying in the future. Hotel as the industries that manage and be responsible need to realize and accept that the information obtained, directly or indirectly, is absolutely necessary in order to position their hotel product and services. On that basis, the role of data collection and research on an ongoing basis will rise to the surface as one alternative for obtaining information on the condition of the existence of hospitality in Bandung. This information is necessary for the hotel as a base for planning.

3. The human factor is a core factor. Therefore, the success of a product 
differentiation strategy services will depend on the human factor in this case is an employee of the hotel. The findings of the research concerning the human factor has the impression neglected, resulting in low motivation of employees. On that basis, it is suggested that the management of existing hotels in Bandung need to consider the following matters: 1) Placement of employees according to their expertise; 2) need to hold trainings for employees; 3) there should be rotation of employees; 4) provide an appropriate reward; 5) provides strict sanctions to employees who dereliction of duty; 6) provide the opportunity for employees to follow higher education.

4. Further studies to enhance the science in the field of marketing, particularly regarding service product differentiation strategy as one of the marketing function to make it more efficient. Further research is intended to know the various aspects that influence the differentiation of service products, beyond the aspects studied in the this research.

\section{BIBLIOGRAPHY}

[1]A.J.Veal, Research Method for Laisure and Tourism, Longman, Sydney, 1993.

[2]Cooper \& Emory, 1999. "Metoda Penelitian Bisnis", Erlangga, Jakarta.

[3]Christine \& Muhleman, 1997. "Service Operation Management" Prentice \& Hall, London.

[4]Dillon and Goldstein, 1984. Multivariate Anaysis : Methods and Apllications, John Willey \& Sons, Inc. Canada.

[5]Ditjenpar Depparpostel. 1997. Visi Pariwisata Tahun 2005. Jakarta

[6]Graffin, Jill. 1995. Customer Loyalty : How to Keep, How to earn it, New York, Lexington Books.

[7]Hill, Nigel, 1996. Handbook of Customer Satisfaction Measurement, Great Britain at The University Press, Cambridge.
[8]Inskeep, Edward. 1991. Tourism Planning, An Integrated and Sustainable Development Approach. Van Nostrand Reinhold. New York.

[9]Kotler, Philip, 2000. Marketing Management : Analysis, Planning, Implementation, and Control, The Millenium Edition, Prentice Hall International, New Jersey.

[10]Lavelock Cristopher, 1996. H, Service Marketing, Third Edition, Prentice Hall International, USA.

[11]Morrison, Alastair, 2010 . Hospitality \& Travel Marketing . USA : Delmar Cengage alearning

[12]Nazir, Moch, 1997. Metode Penelitian, Ghalia Indonesia, Jakarta.

[13]Oliver, Richard.L. 1997. "Satisfaction, A Behavioral Perspective on the Consumer", Toronto, Vanderbilt University, The McGraw-Hill Companies, Inc.

[14]Wheelan \& Hunger, 1995. "Strategic Management \& Business Policy" Addison-Wesley Publishing Company, London.

[15]Zeithaml \& Bittner. 1996. Service Marketing. Singapore. Mc Graw Hill Companies. 